\title{
The law and economics of class actions
}

\author{
Juergen Backhaus • Alberto Cassone • \\ Giovanni B. Ramello
}

More than four decades ago in The Logic of Collective Action, Olson (1965) provided the evidence that in specific circumstances the uncoordinated action of individuals can be less efficient than coordinated action. He was essentially targeting public goods. Nonetheless, this attitude sometimes extends to different goods even though a large number of individuals have a common interest. The Olson contribution was therefore a meaningful explanation for the formation of groups and, as a by-product, for the emergence of specific institutions devoted to making coordination possible.

However, co-operation and organization can not only better serve the private interest of individuals but can be "the most powerful tools human reason can employ" for expressing human liberty (Von Hayek 1960, p. 37) in a wide number of settings, from the market to the political and government systems where other means are ineffective.

An important question is thus whether the previous reasoning equally applies to the judiciary: certainly this is an important topic for law and economics research. Generally speaking, in a number of cases legal actions can be brought collectively and imply some coordination, such as for criminal lawsuits involving a number of victims or for litigations fostered by a public company, involving, albeit indirectly, all the investors. However, this only concerns limited situations.

J. Backhaus

University of Erfurt, Erfurt, Germany

\section{A. Cassone}

Department of Public Policy and Public Choice, POLIS,

Università del Piemonte Orientale, Alessandria, Italy

G. B. Ramello ( $\square)$

Department of Public Policy and Public Choice, POLIS,

Università del Piemonte Orientale, Via Cavour, 84, 15100 Alessandria, Italy

e-mail: giovanni.ramello@sp.unipmn.it 
For other issues, an alternative (substitute or complement) to legal action, still working on behalf of a somewhat coordinated multitude, is represented by regulation, once again devoted to ensuring outcomes consistent with social objectives.

Yet, in a number of cases where large numbers of individuals are characterized by a common interest, none of the previous instruments are able to work and indeed the problem observed by Olson (1965) seems to re-emerge. The eventuality, of course, involves the enforcement of individual rights-i.e., a meritorious claim is not litigated for imperfection of the legal systems-, but equally social welfare as the production deterrent will be sub-optimal and the uncertainty of the protection system will determine a firm's decisions and performance (Chiou et al. 2010; Porrini and Ramello 2011).

All in all the natural question arising is whether a solution exists able to defeat the enounced shortcomings by permitting a more or less coordinated action in the judiciary. The puzzle is not trivial to solve as one of the reasons for the failure of the judiciary is indeed the structural high cost of coordination.

Class action is an affordable though controversial solution as it provides a powerful means for gathering dispersed interests and transforming them into a venture in which the different parties concur to promote individual and social interest. It can restore the full working of the tort law by promoting the (private) compensation of defrauded victims and in turn pursuing the minimization of the social cost of accidents.

This opportunity coupled with a systematic under-protection of victims has led to the emergence of what could be termed a party in favour of introducing class action into several legal systems. A number of countries have already done it with a certain degree of success; others are currently experimenting with class action-like devices, although somewhat lacking some of the constituent features characterizing this procedural device; others, finally, are discussing its introduction. While there is no lack of critical voices, especially from the side of the could-be defendants, the systematic under-protection of victims actually is urging national lawmakers to find a proper answer to the incompleteness of liability systems, whether this will be class action or something else. ${ }^{1}$

One pillar of the debate relies upon the technical possibility for transplant, as class action is a legal device springing from within the US common law system and this of course reinforces the enactment of the US model elsewhere. The answer to the question is better provided by comparative law scholars that have already shown how many changes in legal systems can indeed be explained primarily by legal transplants and how vital this process of cross-fertilization is to legal development (Mattei 1994; Ewald 1995).

The other pillar, beyond the ideologies, is connected to whether class action is a proper device for reaching the claimed results and what should be the right design to make the system workable.

\footnotetext{
${ }^{1}$ See, for instance, the debate within the European Commission (among others referring to very recent public consultation on "Towards a Coherent European Approach to Collective Redress", SEC(2011)173 Final, Febuary 4, 2011).
} 
The articles gathered in this issue try to summarize the law and economics of class actions, disentangling pros and cons of class action lawsuits and providing useful insights for lawmaking.

The debate starts from the historical backdrop of US experience wisely sketched out by Calabresi and Schwarz (2011). Their contribution represents a full window through which to observe the reality of class action today and through which the main concerns about cost and benefit of the legal device are raised.

Ulen (2011) continues the discussion and understandings by giving the reader a comprehensive law and economics framework summarizing the theory and the practice of class action litigation in the U.S. His chapter sketches out at a general level the economics skeleton of this idiosyncratic legal device of the American legal procedure for making possible the assessment of efficiency, the focus of law and economics analysis

Cassone and Ramello (2011) go further on this path of disentangling the economic rationale of class action, by considering it as a mere technology albeit "legal". The stylization thus permits to highlight the productive features in connection with attorneys', victims' and society's interests. From a productive perspective - and in accordance with a large body of mainstream economics literature-class action can thus reveal itself as a legal machinery projected to efficiently tackle the conundrum of the judicial market failure and the promotion of social welfare.

One of the main features of this idiosyncratic new market lies in the possibility to share the risk among parties, which, according to the article by Backhaus (2011), is indeed one of the main contributions of class action. The result can be obtained by swinging the financial arrangement governing the lawyer-plaintiff relationship from the fee-for-service to the contingent fee even though, of course, cases exist in which class action can also fail itself.

Cenini et al. (2011) reinforce the law and economics understandings by studying the effect of alternative procedural regimes on the effectiveness of punitive damages and class actions. On the one hand, their findings can be explicative for the slow motion characterizing the introduction of class actions in Europe and, on the other, they provide strong hints in favour of using class actions and punitive damages in order to create optimal deterrence.

Deffains and Langlais (2011) approach the analysis from an informational point of view, studying a setting in which the market failure characterizes the production of evidences, testimonies and expertises. When victims are injured by the same tort-feasor, a system relying upon individual action ensures that the first mover is benefiting the subsequent plaintiff while class action is a way of internalizing the informational externality with some features from the welfare perspective.

On the contrary, Sacconi (2011) reminds us that 'all that glitters ain't gold', as some shortcomings can arise owing to contingent fee remuneration schemes. His argument relies upon the principal-agent modelling and the outcome underlines that everything depends on whether the conduct complying with fiduciary obligations is performed in equilibrium. When this is not the case, according to Sacconi, a lawyer can fail to maximize the client's interest. 
A similar warning comes from the chapter by Harnay and Marciano (2011) that deals with the possibility of using class action as a rent-seeking technology in the judicial system when rent-seeking technologies in the political market are not available or inefficient.

However, as we have learnt from Roman law,"Abusus non tollit usum", 2 and this seems to be the case of class action, which so far appears to be the only available instrument for overcoming a systematic under-protection of victims.

\section{References}

Backhaus, J. (2011). The law firm as an investment bank in class actions. European Journal of Law and Economics. doi:10.1007/s10657-011-9234-y.

Calabresi, G., \& Schwartz, K. S. (2011). The costs of class actions: Allocation and collective redress in the U.S. experience. European Journal of Law and Economics. doi:10.1007/s10657-011-9233-z.

Cassone, A., \& Ramello, G. B. (2011). The simple economics of class action: Private provision of club and public goods. European Journal of Law and Economics. doi:10.1007/s10657-011-9254-7.

Cenini, M., Luppi, B., \& Parisi, F. (2011). Incentive effects of class actions and punitive damages under alternative procedural regimes. European Journal of Law and Economics. doi:10.1007/s10657-0119241-z.

Chiou, W. J. P., Lee, A. C., \& Lee, C. F. (2010). Stock return, risk, and legal environment around the world. International Review of Law and Economics, 19(1), 95-105.

Deffains, B., \& Langlais, E. (2011). Informational externalities and settlements in mass tort litigations. European Journal of Law and Economics. doi:10.1007/s10657-011-9237-8.

Ewald, W. (1995). The logic of legal transplant. American Journal of Comparative Law, 43(4), 489-510.

Harnay, S., \& Marciano, A. (2011). Seeking rents through class actions and legislative lobbying-a comparison. European Journal of Law and Economics. doi:10.1007/s10657-011-9242-y.

Mattei, U. (1994). Efficiency in legal transplants: An essay in comparative law and economics. International Review of Law and Economics, 14, 3-19.

Olson, M. (1971) [1965]. The logic of collective action: Public goods and the theory of groups (Revised edition ed.). Harvard University Press.

Porrini, D., \& Ramello, G. B. (2011). Class action and financial markets: Insights from law and economics. Journal of Financial Economic Policy, 3(2).

Sacconi, L. (2011). The case against lawyers' contingent fees and the misapplication of principal-agent models. European Journal of Law and Economics. doi:10.1007/s10657-011-9243-x.

Ulen, T. S. (2011). An introduction to the law and economics of class action litigation. European Journal of Law and Economics. doi:10.1007/s10657-011-9252-9.

Von Hayek, F. (1960). The constitution of liberty. Chicago: University of Chicago Press.

\footnotetext{
${ }^{2}$ The meaning is that "abuse shall not prevent the [proper] use".
} 